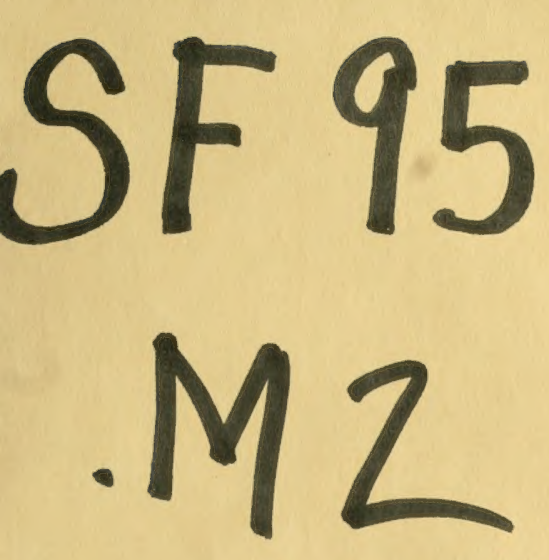





\section{FEEDING AND FARMING}

SF 95

$\mathrm{M} 2$

Copy 1

OVER TEN YEARS OF FEEDING IN THIRTEEN STATES

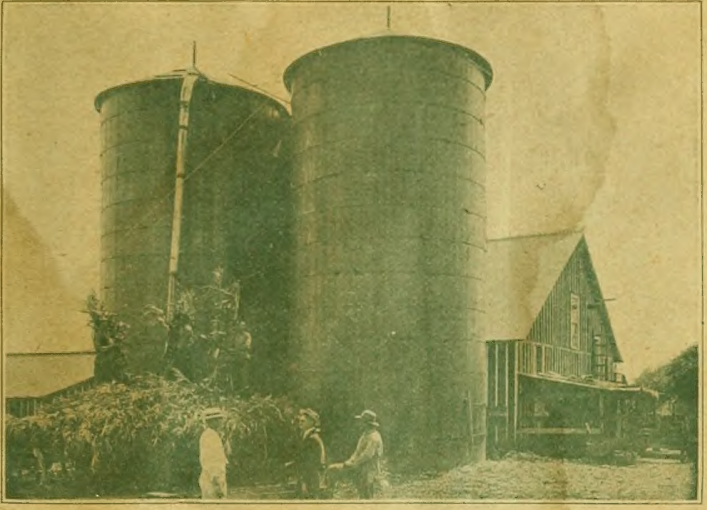

Every cent taken from the cost of production adds to profits.

$$
92 \text { 棵 }
$$

Prices depend on markets; but the south with its climate clips over one-third from the cost of producing meat.

"During the winter months expensive gains are almost always encountered, no matter what kind of live stock is being raised or fattened. The cost of summer gains was small."-Bul. 157 U.S. Bureau Animal Industry.

Compiled and Published by

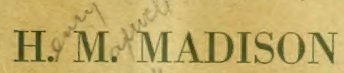

SAN ANTONIO, TEXAS

(Pamphlet Edition)

Price 25 Cents

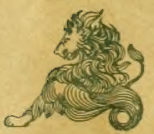

(Copyright 1914 by H. M. Madison) All Rights reserved

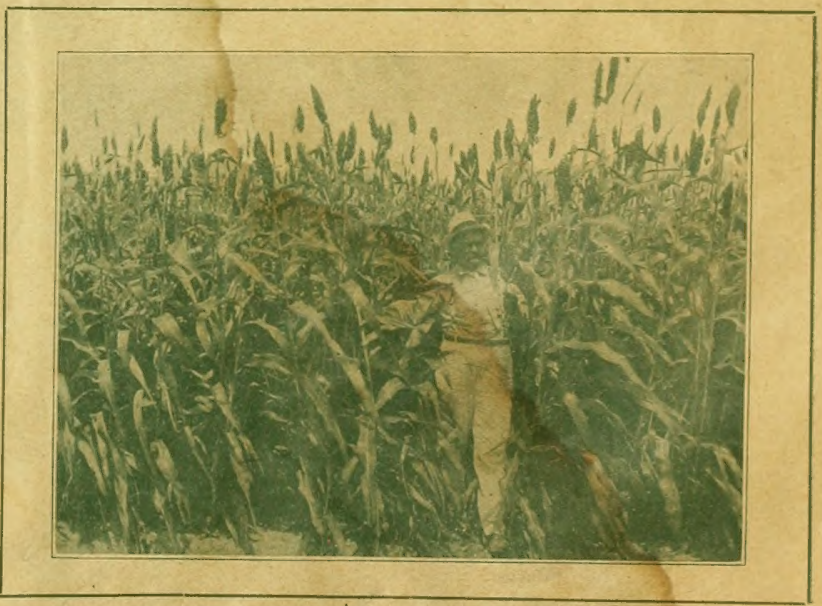




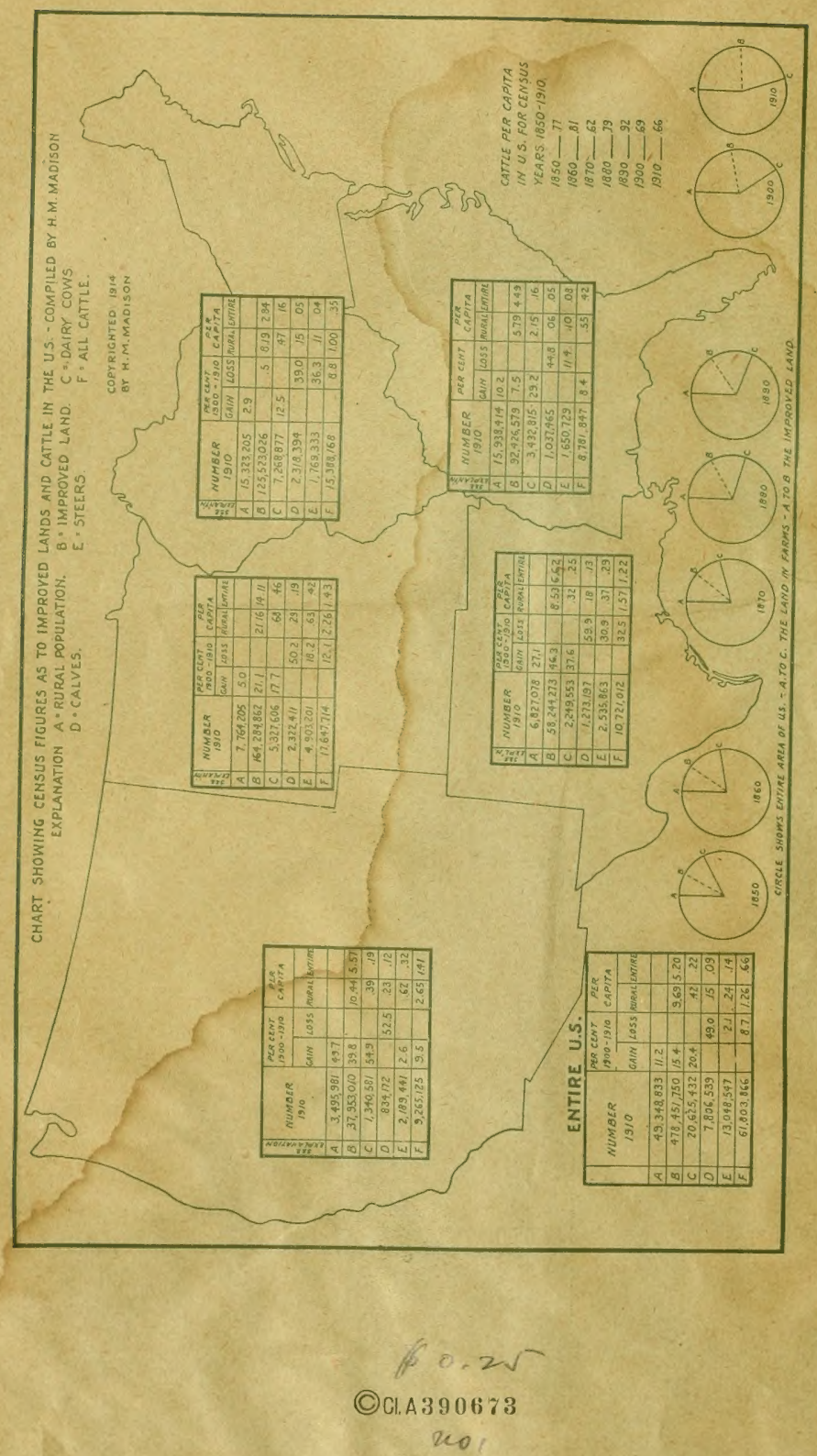




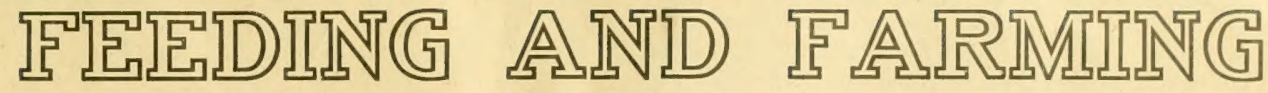

\section{PAMPHLET EDITION}

(Copyright 1914 by H. M. Madison)

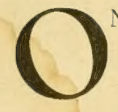

NE of the most striking things about north-

ern and eastern eattle feedings is, that of the feeds used in the published reports of the tests in northern States, there was 14.3 per cent (in cost) shipped in from the south; while every ounce of the feeds used in southern tests was absolutely home grown.

Another striking fact was that there was fed, per steer, in the north, almost as much cotton-seed meal and similar products, as in the south-the exact figures being, an average of 314 pounds of cotton-seed meal and 59 pounds of oilmeal per steer, in the northern States; and 411 pounds of cotton-seed meal in the south. This fact is rendered the more vividily striking by remembering that the average grain fed in northern States was 2.026 pounds per steer; and only 127 pounds in the south.

The amount of dry roughage fed in northern States was 823 pounds, per steer, as against 875 pounds in the south.

But there was a notably less amount of silage used in the south, the one feed that reduces the cost of gains more than any other; the average amount used in the north was 2.554 pounds per steer; and only 830 pounds in the south-had there been as much increase in the silage ration in the south as in the north in the past few years, it is not improbable that dry roughage would have disappeared from southern feed lots, and the cost of grains shown a further reduction.

Briefly summarized, the feeds of the north and south were practically equal as regards cotton-seed meal and similar produets, and also as to dry roughages; while in the northern States there was used three times as much silage and sixteen times as much grain as in the south.

It is frankly said that the feeding term is a little longer in the north than in the south, but this will not account for the excess expense of producing a given number of pounds of meat in the north as compared with the south. In the 267 feeding tests which are investigated and compared in this booklet there was approximately 240,000 pounds of beef produced in southern tests, at a cost of about $\$ 12,000$; while in northern tests there was produced about 236,000 pounds at a cost of about $\$ 19,000$ - these are of course round numbers, and do not include States herein classed as eastern or western-the detailed figures will be found in euts 1 to 7 , at the latter part hereof.

\section{Vital Facts}

Such facts as these are of more than passing moment-they have far more than simply news value; they concern the economic production of one of the largest single elements of the food supply of the country and the world; they materially affect the problem of "the high cost of living"; they will exert a most powerful influence on the development of agriculture in the south; they will very materially affect the rapidity of the colonization of the vast tracts of idle lands in the southwest; they will positively help the railroad, banking, business and commerce of the, entire south; and, in a way be felt throughout the nation and the world.

The facts presented on the following pages would never have been sought out as news items - the many months of patient and laborious investigation and comparison and tabulation would have been spent in more pleasant ways; but it was realized that throngh these investigations there would appear facts that would materially affect the well being of the southwest, the south and the entire country.

It is with no small degree of regret that it is said that there has never been an investigation like the one herein presented. For the most part, the conclusions and facts herein given are new-not new in the sense they have never been suspected by practical feeders for years; not new in the sense that no references have been made to them in bulletins and publications; not new in the sense that no scientific experiments have been made touching upon them-but new, because this is the first attempt to gather widely distributed data from sources that are authentie; then finding a basis for its 
proper comparison; and finally deriving conclusions therefrom, deductively, instead of setting up a theory and trying to find a few eases to illustrate it.

A man once said that it was not difficult to prove anything by the Bible. When asked how, he took two separate and isolated passages and arbitrarily combined them: "Judas hanged himself" - "go and do thou likewise," saying this was proof of propriety of suicide.

A score of absurdities, and absolutely opposing conclusions, could be drawn from taking a few of the 267 tests given herein; but that kind of a proceeding would be both childish and impotent. The conclusions and facts stated in this booklet, are based on a large amount of data - so arranged that it ean be legitimately compared - that furnishes an ample source for deduction. This mass of data is even sufficient to make possible the formulation of some of the fundamental laws that govern profitable beef production, and some of them are given in this booklet-possibly for the first time in a distinct form. It is in these broad senses that the facts and conclusions herein stated are new.

\section{Authority and Sources of Data}

A brief explanation of how the data used herein was collected, and from what sources, is proper. Months ago, authority was given by the Department of Agriculture of the State of Texas, to gather this data.

Letters were sent to the chief State Experimental Feeding Station of every State, and to the Department of Agriculture at Washington, asking all possible information about feeding. Some States had conducted no tests; some had conducted nothing but tests with dairy eattle, hogs, or simply digestion tests - at least published reports of no other kinds of tests were available. The Department at Washington had made many tests in Alabama and these are given as the Alabama tests. In all thirteen States responded with published reports.

Every reported feeding test that was given with sufficient fulness to tabulate has been used. In all there were 267 tests, in which 2.814 cattle were fattened on 47 different kinds of feeds; the cost of the feeds in round numbers was approximately $\$ 55,000$, and the gains made were approximately 700,000 pounds. (See cuts 1 to 7 .)

In each of these 267 tests, the number of pounds of each particular feed was taken and the cost recalculated to a uniform price scale. This price scale was based on the average of prices in one southern and one northern State-Texas and Indiana-and was such as to make the cost of 100 pounds of gain to be about 50 cents less than the average reported in the bulletins of these States. A detailed statement of the prices used herein will be found in the Table of General Data, in connection with the analysis of the feeds used and the statement of their digestible nutrients.

After the cost of the feeds used in each test had been recalculated to this uniform price scale, the results were tabulated and compared, and finally averaged. The one thing always kept in mind and sought for was the eost of making 100 pounds of gain. The buying and selling price of the cattle
Was not considered, nor anything else but that which had to do with the feed cost of making gains.

There were a few cases-somewhat numerous in one State-where the very uneconomic practice of feeding whole grain prevailed, and hogs were allowed to run with the fattening cattle, but as com. pared to the whole number of tests, these cases were too few to materially affect the general average.

In another place, special reference is made $t r$ the cost of barns, sheds and other feeding equipment in northern States. All published bulletins absolutely ignore the interest on the investment in such equipment, its cost of upkeep, insurance and depreciation - as a factor in the cost of fattening cattle; this cost so far overbalances any gain possible by making pork with fattening cattle (even in those tests where the hogs run with the eattle), that one cannot but be surprised that it is not figured into the cost of beef production.

While it is partially inexact, the Glates sending published reports of feeding tests are herein classified as Southern, including Alabama, Mississippi and Texas; Northern, including Illinois, Indiana, and Michigan; Eastern, including Virginia, North Carolina, and Tennessee; Western, including Kansas, Missouri, Nebraska, South Dakota and Wash. ington. These groupings, together with some general average figures, are shown in the lower right hand corner of the cut marked "The Three Influences."

\section{Correctness and Tabulations}

There are several methods of computing averages; the one herein used is to take the average for each single test as to weights and gains of steers, feeds used, their cost, and the cost of gains per head, and per 100 pounds; these figures are used as the basis for all other averages-in no ease was the average of two or more averages taken.

Decimal calculations were not made-this and the possibility of an occasional trivial error in the very extensive computations required, may show extremely slight variations occasionally; but as the compilations were not intended for scientific accuracy, but rather for the purpose of demonstrating facts of vital importance to practical feeders, any such trivial variation is of no moment whatever.

\section{Preliminary Facts}

The upper part of the cut ealled "The Three Influences," contains a chart that reproduces the main rainfall lines of the United States Weather Bureau Chart of Normal Rainfall; the number of inches of normal rainfall, annually, are shown in the figures on each line.

Within this rainfall chart are dotted lines that reproduce the geographic divisions of the United States as adopted by the Census Bureau. In each of these divisions there is shown the number of beef cattle per eapita, according to the census of 1910 , together with the percentage decline since 1880 . It will be seen that the smallest number of beef eattle are in the New England and other northeastern States-it will also be noted that in these sections the decline has been heaviest. To the 


\section{THE THREE INFLUENCES}

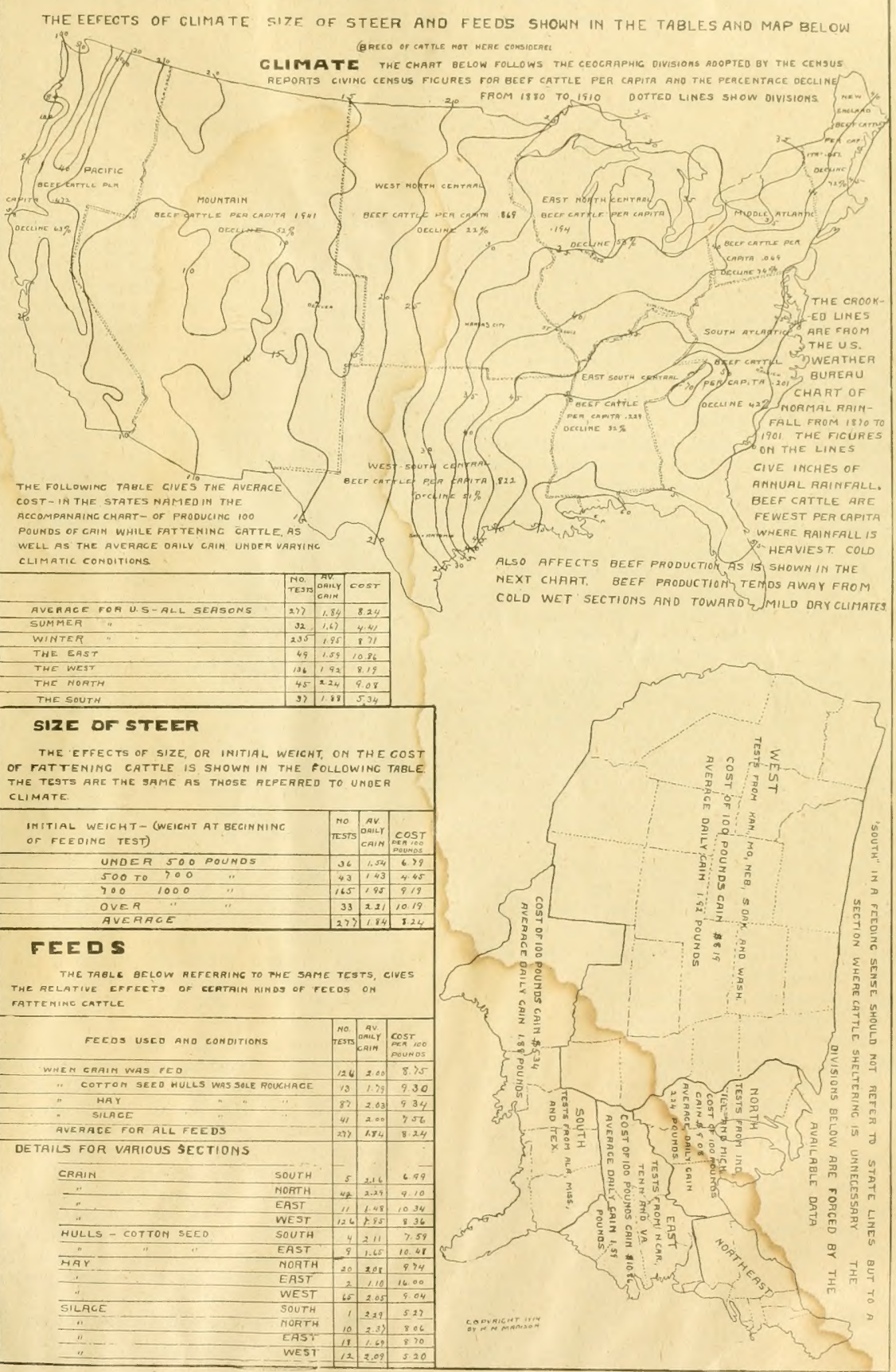


south of this section, in the South Atlantic States, the number of eattle, per capita, is much larger, and the decline much smaller. To the westward from the New England States the number of eattle per capita, becomes greater, and the percentage of decline smaller.

These figures seem to point to the fact that the beef industry suffers most in wet, cold climates, and the relieving it of either element-wetness or coldness - helps the industry, as is seen by traveling southward from New England when cold is relieved, but not wetness; or, as is seen in traveling westward from New England when wetness is relieved, but not cold.

It is not possible to carry this geographical illustration to its legitimate end, for the reason that the States that are grouped in the census reports as the West South Central, embracing Texas, Arkansas, Louisiana, and Oklahoma, have a large part of their territory with as much rainfall as anywhere in the United States, and as a consequence the combined effects of both the drier and milder elimate cannot be tabulated. It is even true that Texas, the greatest cattle-raising State in the union, has a large part of its territory receiving the heaviest rainfall. It is not possible therefore to gather statisties that will show the final facts geographieally, about the fact that as we travel from wet and cold sections to drier and milder ones, the beef cattle industry increases in thrift and profit.

But it would seem that a somewhat close study of this rainfall chart with its beef cattle figures, would clearly indicate that the best beef cattle country lies between the rainfall limes of 15 and 30 inches of normal annual rainfall. Confirmation of this is given by looking at the gradual increase of the number of cattle, per capita, in going westward, till the wetter regions of the Pacifie Coast are reached, where the decline begins.

The general increase of the beef cattle industry as milder climates are reached is so fully treated hereafter that no further statement or argument is here added.

While this general fact, pointing to the success of the beef cattle industry in drier and milder sections would seem to indicate that portion of the southwest lying between the lines of 15 and 39 inches of rainfall as the elimatically ideal section of the United States, there are many other sections of the south where the beef industry is extremely profitable as is abundantly attested by the experiments of the United States Department of Agriculture for the past 13 years in the valley of the Tennessee in northern Alabama, where extremely inexpensive gains have been marle.

\section{The Influence of Size}

It is usually true that the larger the steer at the beginning of the feeding period, the more expensive will be the gains. There is an apparent exception to this rule in the case of young calves in cold or wet weather feeding; their being young seems to make them more sensitive to the effects of inclement weather. As a rule, however, the cheapest gains are made with steers that weigh from 500 to 700 pounds at the time of the beginning of feeding. As the initial weight of the steer increases from 700 the expense of the gains increase somewhat rapidly. In the cut "The Three Influences" the average results of the effect of size on the expense of making gains is shown, under the subhead "Size of Steer." It will be seen from this table that in steer's weighing from 500 to 700 pounds the average cost of gains was $\$ 4.45$ per 100 pounds, while in steers weighing over 1,000 pounds at the beginning of the feeding period, the eost was $\$ 10.19$ per 100 pounds.

\section{Feeds}

The third great influence on the economy of making gains is feed. The details of this influence are brought out under the subhead "Feeds" in the chart of "The Three Influences." These tables show that where hay was used as the sole roughage, the gains were the most expensive, averaging $\$ 9.34$ per hundred pounds; cotton-seed hulls were second, showing a cost of $\$ 9.30$ per 100 pounds of gain; grains came next with a cost of $\$ 8.75$ per 160 pounds gain.

These three classes of feeds made gains cost ahove the average for all feeds, which was $\$ 8.24$ per 100 pounds; so that hays, grains and cotton-seed hulls may be classed as the excess expense feeds.

Aside from pasture, silage was the cheapest of all feeds, showing an average eost of $\$ 7.56$ per 100 pounds gain.

The average difference, in cost per 100 pounds gain, between hays and silage was $\$ 1.78$, or about 23.7 per cent.

\section{The Three Influences}

It was utterly impossible to select from the entire 267 tests enough to illustrate clearly the positive influence of the three influences of climate, size, and feeds-as separate forces-in the different sections of the country. It is enough to have pointed out that these three influences exist in a very positive and unmistakable way, and to gather from 267 tests as many facts as possible with regard to each of the three influences, and to indicate that practical feeders can have due regard for them, and utilize all the advantages possihie while avoiding the expenses and dangers. The chief facts about the three influences are brought out in the charts and tables in the cut "The Three Influences," a careful study of which will prove very illuminating,

The purpose of this booklet is to present the results of investigation into climatic conditions, chiefly. Reference has been made to the effect that feeds, and the size of the steer, has on the cost of gains because it was unavoidable; there is also a fourth influence-the influence of breeding - that is not referred to here at all. But its effects are so well known that almost any thoughtful person will be able to examine the details of the 267 tests in the latter part of this treatise and distinguish the better bred cattle through differences not accounted for by the other three influences.

\section{Feeding Experts and Climatic Conditions}

The State of Washington, on page 6 of Bulletin 79 says 
TABLE OF CENERAL DATA

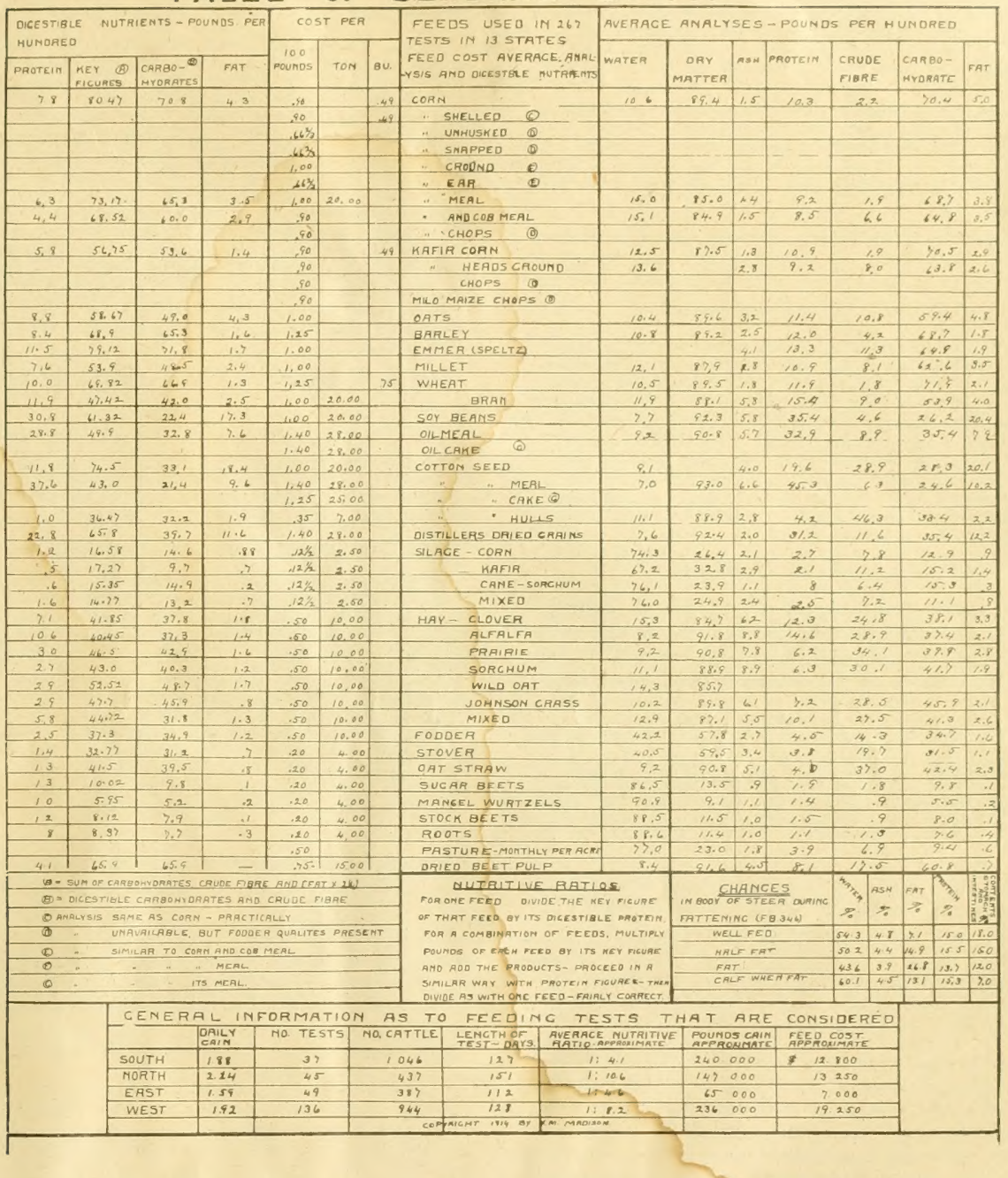

"The shelter needed by the eattle on feed depends very largely on the climate. They need protection from the storms and want dry sleeping and feeding places. In sections where the climate is damp and raw, eattle need a shed and sloping yards that are most apt to keep dry, in order that they may be com. fortable and satisfactory gains be made, while in localities where the weather is dry though somewhat cold, steers seem to do well even without protection.'

Maryland Bulletin 121, on pages 91 to 93 , says:

"Most eattle in Maryland are fed in stalls, open stables and sheds, or in an adjoining lot with a pound. Most of the stall feeding is earried on during the winter montlis.

"There should be sufficient protection, so that the animal will not need to use much more food for heat production to keep up the normal temperature of the body, than is naturally radiated during rapid assimi lation of food.

"The character of the barns and sheds for feeding eattle varies considerably in different parts of the State. The climate of the western counties has caused the farmers to construct large barns for the sheltering of their erops and live-stock while farmers in the southern part, and on the eastern shore, have bult less expensive struetures. Simple sheds have sufficed quite as well. " " Fen barns and little shedding are used during the summer months for beef cattle, but in the winter most of the feeding is done in the barns,"

There is considerable elaboration of these statements in this bulletin, but they refer mostly to detailed conditions, and are not quoted in full.

Missouri Bulletin 112, page 262, says: 
"The test was condueted at the University Ex. perimental Feeding Plant. This includes a series of lots 100 feet long by 19 feet wide, with a 20 -foot shed running along the north side. The lots slope slightly to the south allowing a reasonable surface drainage, but they are not paved and consequently became muddy during bad weather. The eattle were fed grain and silage in flat-bottom feed bunks placed in the lots while hay and shocked corn was fed in mangers provided for the purpose under the shed."

In Kansas Bulletin 113, page 40, is a sentence reading:

"Erch lot of ealves was sheltered with a common
board shed, closed on the north and open on the
south."

Indiana Bulletin 136 says on page 6:

"The lots in which the cattle were fed were $40 \times 50$ feet, with an open shed $12 \times 40$ feet on the west side of each lot. They were built up of einders and gravel and sloped away from the sheds. No bedding was used in the lots. The sheds were kept as dry as possible by a liberal supply of old straw. The mild winter of 1908-9, together with the large amount of rainfall, kept the lots muddy throughout a greater part of the time covered by the experiments. Water was supplied from the town water supply in galvanized iron tanks, protected by 5 inches of manure, outside of which was a wooden jacket 1 inch thick, and a eover, which was elosed during extremely cold weather."

This description is practically repeated in Bulletin 153 with the addition that the lots became very muddy and sloppy, and that some cinders got between the hoofs of the steers eausing, some lameness.

Again this description is practically repeated in Bulletin 163, but it is added that the winter of 1911-12 was cold and the ground was kept frozen till the last few weeks of the test, when the same troubles were experienced with sloppiness as before.

Still once more is the description repeated in substance in Bulletin 167, but it is stated that during the first three months of that year's tests the lots were in a very satisfactory condition, though the-last three months they were bad and were "undoubtedly responsible to a certain extent for the less satisfactory gains on the cattle.'

Just here attention is direeted to the fact that the feeding station of the State of Washington is located in the eastern part of that State where the rainfall is very light-only about 20 inches annually, while the feeding station of Texas is located toward the northeastern part of the State where the rainfall ( 37.37 inches annually is greater than in any west north-central State except southeast. Missouri and equal to that of Michigan, northern Indiana, Illinois, Ohio, the Great Lakes and northermmost New England, as will be seen by looking at the rainfall lines on the chart of the cut "The Three Influences."

A deseription of the feeding pens is taken from Texas Bulletin 159, page 9:

"The pens in which the steers were confined and fed throughout the test were equal in all respects.

They were $60 \times 100$ feet in area, had neither sheds nor vindbreaks, and hence, were entirely unprotected from the weather.'

At this feeding station, in the tests conducted the previous year, the gains were far less economic; but on page 9 of Bulletin 153 is found the chief reason:

The weather conditions were unusually severe during a greater portion of the time the experiment was in progress. A few days after the cattle were started on feed a heavy snow fell and, in melting, placed the pens and the space under the shed in a very bad eondition. This was followed by alternate freezing and thawing so that when the ground was not frozen the mud was knee deep. The steers' feet were very sore and for several days it seemed an effort for them to get to the troughs. These conditions began about December 19, and with the snows that fell in February, the pens and sheds were kept in such bad condition until near the elose of the feeding experiment that there was no dry place for the cattle to lie down. Neither lot therefore made the. gains that they should have made had the conditions been normal,"

Mississippi Bulletin 121 says on page 3 that the steers-

"were placed in one-acre lots fenced with woven wire and containing water. There was no shelter of any kind provided. The weather was excellent during the feeding period, and the stock at no time suffered to any extent from cold winds or rains."

North Carolina Bulletin 218, page 31, says:

"The steers were fed in a barn. The stalls were loeated on the south side and were $15 \times 20$ feet. They were connected with lots $20 \times 80$ feet. The steers were kept in the stalls during the night and a larger part of the day. This system of close housing was fol lowed primarily for the purpose of eonserving the manure, otherwise the steers would have been given free use of the lots. While the barn was elosed on all sides, it was well ventilated so that the steers always had comfortable and healthy surroundings. Bedding was supplied in the stalls and lots in quantities sufficient to retain the manure and keep the lots in dry condition, which was sometimes diffieult in rainy weather.'

The next year conditions were changed so as to provide free access of the steers to a lot $20 \times 80$ feet.

The totally different character of protection required in the south against that in the north is beginning to be already apparent, but will become much more so in the further quotations from feeding bulletins.

Nebraska Bulletin 75, on page 19, describes the sheds and barns used:

"Six steers were confined to open sheds $8 \times 14$ feet with a yard attached of the same size, making a stall and yard $8 \times 28$ feet, in which the steer was confined. This shed opened to the east and was protected from the southwest winds and partially protected from the northeast winds.

"Six steers were also confined in box stalls $6 \times 12$ feet, opening to the south. They had no exercise except when driven to the scales, and the privilege of a small yard while the stall was being cleaned daily. One steer was confined to each stall.

"Six steers were also fed in an open yard $100 \mathrm{x}$ 200 feet in dimensions, having an open sbed $16 \times 24$ feet facing the south, under which they could run at pleasure. They were also proteeted from the north by ra shed 85 feet long and 10 feet high, a tight board fence 6 feet high along the remainder of the north side of the yard.",

The gains reported for the steers fed in the box stalls averaged 401 pounds; those in the shed and yard were 328 pounds, while those in the open shed and yard were 314 pounds. The average cost 
of 100 pounds gain on the steers fed in the box stalls was $\$ 8$; on those fed in the shed. and yard, $\$ 10.06$; and on those led in the open yard and shed,

In this counection it seems proper to refer to Cireular $10 t$ ol the Illinois Experimental Station that gives the details of the reguirements for a feeding equipment for 200 steers. But before this is quoted reference is mate to 13ulletin 142 Illinois, where it is said. "The feed lots proper were paved with brick and measured $36 x+8$ feet, with a shed rumning along the north side. In these small lots cattle were allowed to rum at all times." It is also said of one particular experiment begun very early in the season: "Owing to the prevailing warm weather at the beginning of the experiment, it was thought best not to confine the steers to a small feed lot with no shade other than that provided by the shed. Consequently they were given the run of a small paddoek $237 \times 112$ feet, which adjoined the feed lots."

The signifience of the specifications for the feeding equipment for 200 cattle in Illinois can now better be appreciated. The details of the specifieations are here omitted, and the prices of materials and labor are of the date of $190 t$, and are given below as summarized in the Illinois eircular:

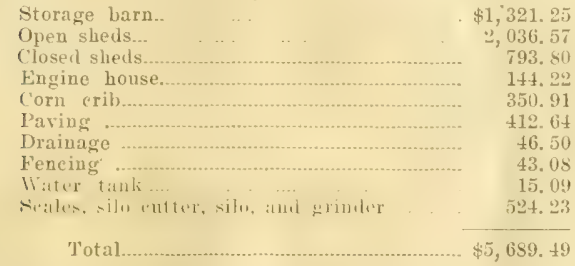

Interest on this investment at the rate of 6 per cent ammally; and insurance, upkeep and depreciation figured at 10 per cent would make the annual expeuse of this plant $\$ 910.24$; being designed for 200 eattle, it would make the cost per head $\$ 4.55$. Using the average daily gain made by the cattle reported in the Illinois bulletin, the cost of this feeding equipment would be \$1.4t per 100 pounds of gain.

If it be said that this investment is unnecessary or exeessive, reference is made to the Nebraska test of different kinds of protection from winter's cold and the results shown; as quoted above these show a difference in the cost of gains made under ample protection as against moderate protection, of $\$ 2.06$ per 100 pounds; and a difference of $\$ 2.84$, as between adequate protection and poor protection. It is simply a question of much more expensive gaius without barns and feeding equipment in northern winters; or, having the expensive equipment and making cheaper gains.

The northern portions of all States bordering on the Gulf (except Florida), are within the snow line, and demand some protection in winter for stock being fed, particularly young calves; in the southeru half of these States snow is practically unknown, and the ouly protection needful is a cheap shed for the rainy weather in winter, and trees for a shade in the summer-the expense of such protec- tion is trivial, and constitutes a very large fir in the economy of beet production. When it is membered that beef has been produced on sonthera pastures for less than $\$ 2$ per 100 pounds, and that the loss in Nebraska as between a poor and good slelter was $\$ 2.84$ per 100 pounds, the significance of the elimatic difference becomes striking indeed.

It remains to make some quotations from the bulletins published by the Department of Agriculture at Washington as to the feeding tests conducted in Alabama. On page 41 of Bulletin 131 the cost of making gains are tabulated (when cotton-seed cake had to be hauled 15 miles) and are given as from $\$ 2.56$ to $\$ 3.21$ per 100 pounds of gain. Below these figures it is said:

\begin{abstract}
"In every case abore, the cost to make 100 pounds of increase in live weight was very low. When steers were fattened in winter time each pound of gain is put on at a loss, as each pound put on may be expected to cost from 8 to 12 cents, and the profit, of course, dependent on the enchancement of the value of the steer over and above the selling value of pounds of gain made.'
\end{abstract}

Another test is referred to on page 32 of Bulletin 157:

\footnotetext{
"It cost $\$ 8.63$ to make 100 pounds of gain during the winter period but the gains were made for only $\$ 4.5$ when the calves were on pasture and received a partial ration of cotton-seed cake and alfalfa hay. * * * During the winter mionths expensive grains are almost always encountered, no matter what kind of live-stock is being raised or fattened. " * The cost of summer gains was small compared with that of the winter gains, yet these summer gains were unusually expensive.'
}

The tests referred to were conducted in northern Alabana and the series of bulletins referring to them are most leartily recommended to all cattle feeders.

\section{Heat and Flesh Producing Feeds}

The wide ditterence between the tiet of whale blubber and tallow candles in the aretie regions, and of cocoanuts and bananas in the tropics forcibly illustrates the difference in feed requirements of the north and south. Fats, the strongest of all heat-producing foods, is the one great essential in the aretics; foods with practically no fats, and the minimum amount of other heat-producing elements are what is required in the tropies. In the subtropies, and in the warmer portions of the year in the temperate zones, less fat meat is used and required by man.

Broadly speaking, there are two general and very distinct qualities in all feeds. These two distinct qualities are composed of severil elements, but the consideration of them is for the chemist, rather than for the practical feeder. Roughly speaking, these two distinct qualities may be called the flesh-producing and the heat-producieng qualities; the general name of Protein is applied to the flesh-producing quality, while three names are usect in connection with the heat-producing one-Crucle Filue, the most indigestible and least raluable element in feeds: Carboluydrates, the largest factor in grains; Fats, the most powerful heat-producing element known. 
In no possible may can the lieat-producing elements take the place of the Hesh-producers; but, under some conditions the flesh producers ean take the place of the lieat producers.

Heat producers also furmish all the energy that the animal requires for moving about and digesting feeds; whaterer is not needed for keeping the body warm or used as energy, is either radiated from the animal's body or stored up as fat. The importance of keeping a fattening animal quiet and in quarters where cold and wet weather will not affect it is at once apparent, as the oue chief purpose in fattening cattle is to store up fat in the systemthe flesh gains being comparatively trivial.

The proportion in which the flesh and heat-producing elements exist in any particular feed is called nutritive ratio; the figure 1 represents the Proteins, while some other figure that shows the relation of the heat producers, represents the heat elements-be that figure $4,7,9,11$, or any other number.

Only a certain portion of the Hesh and heat-pro ducing elements are digestible, and these are called the Digestive Nutrients. In recent years it has been the eustom to only use the Digestible Nutrients in making up the Nutritive Ratio.

To find the Nutritive Ratio of any feed, multiply the Digestible Fat by $2 \frac{1}{4}$, and add to this product the Digestible Crude Fibre and Carbohydratethen divide this sum by the Digestible Protein; the quotient will be the figure that represents the heat producers.

The Table of Genexal Data gives the average analysis of the 47 feeds used in the 267 tests that are the subject of this treatise; also the percentage of Digestible Nutrients-both these are for the most part taken from Bulletin 321 of Cornell University, and Farmers' Bulletin 22 of the Department of Agriculture.

It will be seen by the Table of General Data that the average nutritive ratio of feeds used in the south was approximately $1: 4.1$, while in the north it was $1: 10.6$-in other words, there was about two and one-half times as much of the heat-producing elements, proportionately, in the northern as in southern feeds. In the western States this proportion was double that of the south; while in the eastcrn States from the standpoint of templature more nearly southern), the ratio mas higler than in the south.

There is also given on the wht. Talle of General Data, the changes that take place in the body of the steer during the process of fattening. In all the elements of the body there is an actual gain in pounds, but the proportion of these elements change, so the figures are given in percentages. The ratio of the water decreases. while the fat is more than trehled.

lunt in a calf, there is a larger per eent of water and a smaller : imount of fat.

It is curissis, perlaps, to note that the initial weight of rattle fattened in the north is greater than fires in the sonth. As the accumulation of fat is greater in steers of heavier weight, they furvish weat that is better adanted to the rigors of the rold of northern winters; but the smaller steers, with their less accumulation of fat, furnish meat better adapted for summer use and in those sections where cold is not so much in evidence.

\section{Special Phases of General Averages}

An examination of the cut-The Three Influences -will show that the cost of making 100 pounds of gain averaged as follows:

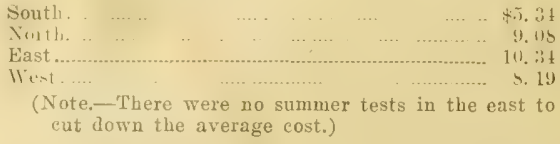

In order to center attention on the fact that the cold of the north and other sections was a positive tactor in the cost of making gains, the summer and winter average cost for making 100 pounds of gain in all sections is referred to-these costs were as follows:

Summer 4 เ. 41

Winter. ?. 71

Where grain was fed the special averages showing the cost of 100 pounds of gain are given below:

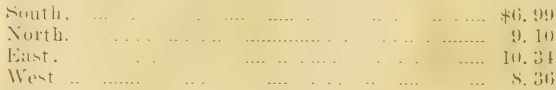

Cotton-seed hulls were not fed in the north, nor was hay fed in the south as the sole roughage; but in feeding-cotton seed hulls as sole rougliage, there was a difference of $\$ 2.89 \mathrm{per}^{*} 100$ pounds of gain in favor of the south over the east.

As the sonth did not feed hay as a sole roughage, there is no average figures to compare.

As there was only a single test where silage was fed as a sole roughage in the south, average figures are impossible; again, the steers in this one test had an initial weight of $82 t$ pounds, but in most of the western tests the cattle used were young, so there is a bad basis for auy comparison; with this explanation of it will be easy to understand the slight favor of the west over the south on this mal-proportioned comparison :

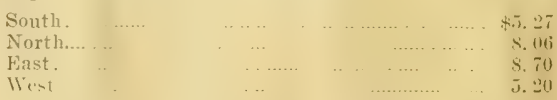

Special averages based on all initial weight classifications (under 500 pounds -500 to $700-700$ to 1000), for the south, north, east and west cannot be shown, as all sections did not feed eattle coming under these initial weight classifications. Under only one of them (700 to 1000) was there enough tests in all sections to make the comparison legitimate-the cost of 100 pounds of gain under this classification averaged as follows:

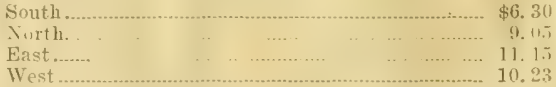

It is fair to add that as far as the results obtained under the other elassifications show anything, they indicate the same ratios as in those just given.

\section{A General View}

It has been scen that northern cattle eat practically as much dry roughage and cotton-seed meal 
(and similar) produets as those of the south; it has been seen that the grain (chielly heat-producing) ration of the morth is many times in excess of that for the south; it has been seen that the nutritive ratio of northern feeds shows proportionately, ahout two and one-hali times as much of the heat-produce ing elements, as those used in the sonth-so it is fiar. say that northeru fields must be made to grow hear produciug feeds to such an extent that they may be partially likened to a coal mine; that northern corncribs are partially like a coal bin; and grain is given to eattle partly for the jurpose of being burned (by animal oxidization) to furnish the required heat to carry them through the rigors of cold, and the exposure to rain and sleet and suow.

It has been seen that main and mud and snow are disastrous to the feeders' profits; it has been seen that the fewest cattle are in the cold, wet climates; it has been seen that the ratio of declines in the number of eattle is greatest in these cold, wet climates; it has been seen that relief from either wetness or coldness makes the raising of cattle more profitable, and that the relief of both wetness and coldness furnishes still greater opportmity for profits; it has been scen that a warm, dry climate is a positive asset to the cattle industry; it has been seen that the expense of a feeding equipment in the north adds materially to the cost of beef production; it has been seen that stummer gains are made more cheaply thau winter gains; it las been seen that with any of the more general classes of feeds that gains are made in the south more economically than in any other section of the country; it has been seen that from any angle of consideration that gains can be made in feeding eattle more cheaply in the south than in the east. west or north-so that all these things point inevitably and conclusively to the direct, positive and powerful influence of elimate on the cost of producing beef.

From whatever viewpoint beef production is considered-census reports, rainfall chart, temperature conditions, geographic distribution. puantity of feed, nutxitive ratio of feeds, cost of making gains, or care and expense in sheltering-there stands out clenrly and boldly the striking influence of climate, even the quality of beef produced scens, in some way to tell ahout elimatic conditions.

Enough data and facts have been adduced to make possible the announcement of a law that gorerus beef production-a law that may be very simply stated in ordinary business language:

Cold, wet weather increases the cost of beef production; dry, mild climates decrease the cost.

\section{Sufficiency of Feeds in Dry Climates}

But granting that the gains of the south are made at a lower cost than elsewhere, is there any question of there being such climatic eonditions that there caunot be enough feed raised to take care of the feeding needs, particularly in the western or drier parts of the south?

The first answer that will be given to this possible query is, that the north found it newssary to import from the south 14.3 per cent (in valuo' of the feeds used in the faeding of eattle in tests re ported in the published bulketins, while the soutl did not find it needful to get an ounce from any place but her own fields.
The second answer is that in 1880 , (it)

the eattle of the Lnited states were teast of

sissippi River, while in 1910 the (rensils sll

almost 61 per cent wer\% west of it.

heary rainlall is east of the Mississippi, but th

the of the country latve gone to the lexpions west

the Father of Waters where the rainfall is lightit is in these dry cimates that the eattle inclustry of the country has thriven liar more than in sections where the rainfall was great.

As feeds are essential to the growing of cattle, the answer as to the sufficieney of feed growing in the south and the drier parts of the soutlawest, has heen very largely given. I3ut a further answer is formel in the-

\section{Type of Feed Crops}

In the drier regions west of the Mississippi River, particularly in the southerm portions of these regions, there hats been developed a type of crops that is different from those used in the rainbelt ser:tions. In these drier regions corn is ceasing to be the "one and only" great feed erop). In its place are others that are proving themselves more productive, not only in these drier sections but actually yiclding a larger production, per acre, than does corn in the rainbelt regions. 'These types of erops do not dry up) and "fire" or parch or witler, in "dry spells" or drouths-they simply stop grow. ing, and start again with the next rain. There are many varieties of these types of crops, but they are coming to be familiar under the general names of Kafir Corn, Feterita and Milo Maize. Kansas feed. ing tests have shown that, as silatge, ther have more fattening value than corn; as grains, they are acknowledged hy all competent authorities to have 90 per cent of the feeding value of corn.

Among the hay erops sorghum has a demonstrated value that puts it beyoud timotlyy or any similar grass, both as regards feediug value and tonnage per acre; besides it has the same drouth resistant power as Katir Corn. Sudan grass is also coming to be recognized as a great lay crop.

In pastures, the sonthwest has an advantage not possessed by the north, west or east; for pastures can be maintained throughout almost the entire winter-in fact, in most of 'South Central 'T'xis, pasture can be maintained for the entire winter. Among the winter pasture crops are bur elover, oats, winter wheat, rape and rye. In the very early spring comes that greatest of all pastures for produeing gains eheaply - white sweet elover. I3y graneing at Cut No. 1, and noting the gains made on pasture, it will be seen that there has never been stch low-priced gains made anvwhere in the United States, and this pastrue was white sweet clover: ehictly. It is to be regretted that there is not more of this greatest of all pastme grasses grown, but as its ralue becones hettur known its extensive nse is more than assured. There are native and other grasses that have heen the hasis for the sureessful growth of cattle for more than a) century, and to the use of which some of the greatest fortumes of the southwest owe their existence. Fortumes are living monmments attesting. incontrovertibly, the success of the country as a eattle producers.

Grain and hay crops can he harvested from one 
to three times ammually; alfalta ean be cut from three to eight times per season.

\section{Special Soil Conditions}

By many the San Antonio Country has been called "semi-arid". Taking this section as a type of the drier regions of the mild, dry climates, it may first be said that the rainfall of the San An tonio country is about the same as the producing portions of Kansas, Nebraska, Iowa, Minnesota, the Lakotas, and the northern Lake Superior region, as cau be seen by examining the rainfall chart herein. Some generations ago the sections above named were called "dry", but this ery has passed, and iu the same way the cry will pass as to the San Antonio country, and there will be a reason-this reason will have reference to the special soil conditions.

Any man fully conversant with the vast territory of South Central 'lexas (exceeding in area the entile of New England, New Jersey, Delaware and Maryland), has noticed that the early farmers went to the poorer sandy lands; he has also noticed that by far the larger part of the improved lands are of this sandy character. He knows that the rich, valley lands - the rich loams and clays are for the most part untouched.

The comparative stranger will sometimes ask why the "sandy land farmers" are given credit more fully than those on the "rich lands" ; and will marvel at the superior appearance of the "sandy land farms" and the wild, raw look of the "rich land farms" .

There cau be no question but that the sandy lanis are poorer in quality than the loams and clays-and these two elasses of lands are so intermixed as to make the idea of one receiving more rainfall than the other is an absolute absurdity. Every possible explanation seems to have been attempted, bui the plain, simple, and only obvious one.

The sands are, by nature, open and loose; whenever it rains they take in whatever rain falls. On the other haud, the loams and clays have been packed by centuries of rainfall, the tramping of millions of butfalo and cattle, and the marehing ot armies and the travel of men. No freezes have ever come to mellow these rich lands, and ther lic there in all their centuries old compactness. Wihenever rain falls, they do not take it in as do tile sands, but they shed it like a roof-they rum flic. rainfall off flown the streams to the rivers and in the gulf, creating floods that wash away bridges, overtlow lowlands aud create general havoc.

A careful examination of the reasonably level saudy lands fails to to show any surface rashing, streamlet channels, or any other evidence of the rainfall running off; it lias gone into the soil. A careful examination of the sulb-soil of the sands will show moisture at almost any season; the digging down to an impervious bed below the sands will ilways reveal a shallow well.

examination of loams and clays (in their raw state), will show erosions, little sireamways and, washing almost anywhere; the sub-soils will almost invariably be dry; and no amount of digging will reveal a shallow well.

The rainfall on the sands has been sufficient to make a moist sub-soil, plenty of shallom wells and sure (but ruther small) crops. Precisely the same amount of rain falls on the adjoining rich loams and clays. What is the inevitable conclusion? It was the quality of looseness that caused the sands to take in the rain and make the subsoil moist, create the shallow well, and bring forth sure crops.

Cannot the loams and clays be made loose? They are lich. To sureness of crops they can be made to add largeness.

Nor is this theory. It has already been accomplished in the section about Taylor, as well as in other places. Something of this kind has happened in the prosperous west north central States, and it has been repeated over and over again in other sections of the world.

Loosening of the soils of south-central Texas by the use of the plow in the fall has accomplished more for the few farmers that have tried it than all the irrigation systems that have been devised, though it is frankly said that the irrigation systems very much add to the producing possibilities of many lands. The point here urged is, to save the rain as it falls and where it falls-to get it into the soil at once, instead of waiting till it runs down some stream and is impounded behind a dam and earried by ditches to the crops; or, till it sinks into the artesian beds and is drilled for and pumped out and carried to the fieldside.

Plowing is more economic than artesian well drilling, or dam and reservoir building. Get all the moisture in the land possible through rainfalllet artificial irrigation supply what is absolutely required in emergencies.

\section{A Deaf Ear}

The question of raising adequate supplies of feeds in the drier portions of the southwest depends, very largely, on turning an absolutely deaf ear to any one adrocating shallow, spring plowing of clays and loams, and the plowing of them deeply in the fall, so they will take in the stock of fall and winter rains; next, to cultivate the crops frequently so that a soil mulch will be maintained to prevent summer evaporation. No farmer who has intelligently adopted deep fall plowing and frequent shallow crop cultivation has ever liad unusual reason to complain of drouths in the southwest, nor has he failed to raise satisfactory crops as to both size and sureness.

Drouth is not the trouble with lands in South Central Texas - the trouble is the slavish adherence to customs that invite and have always brought more or less disaster, and a refusal to consider methods that offer good results.

\section{The Silo}

Inasmuch as silage has been shown to be the feed that produces gains with less expense than any other, a brief reference to the silo is not only proper, but necessary.

There are now in the United States over 800,000 silos, but hardly 1 per cent of them are in Texas, the greatest eattle-raising State in the Union. The great pasture areas offered such advantages for growing cattle, that feeding them has been to a large extent lost sight of, but now that the silo is beginning to appear, fattening cattle is coming to he an industry of importance. There are States with less than one-fourth the area of Texas that 
have five times as many silos, and the dilect of these, in the other States, in lowering the cost of fattening eattle makes the dispropontiouate cost oi Texas tests appear as a gross injustiee to the lone Star State.

In a greneral way, it may be said that erops fed as grain and dry roughage lose about 38 per eent of their nutritive elements, as against only about 10 per eent in the silo. To put it differently-a 100 acre finm only furnishes nutrieuts to the extent of a 62 -acre farm when the crops are fed as grain and dry roughage, while if they are fed as silage, the loss is trivial.

The modern silo is built of wood (staves or some like material) lrick, stone, metal or exment. They may be abote or below ground. It is out of place here to diseuss the various kinds of silos, further than to say the material used is, very largely, to be judged in the same way as material for a building -by its durability, its ability to withstand storms and the elements, its insurance aspect, and its cheapness or expeuse. But whaterer material is used, there are a few things that can never under auy circumstances be lost sight of; these are first and moremost that the silo must not only be water tight, but must be airtight-this is an absolute essential. The next most essential thing is that the diameter be uniform from top to bottom and that the inside walls be smooth. Among other things needful is that the height or depth be from two to four times the diameter; the best shape has been demonstrated to be the round form.

\section{The Silo Cutter}

The green crops are hauled to the silo and run through a power entter that chops the stalks, stems, leaves, ears and heads into lengtlis of a little over one-quarter inch. By a "blower" usually, or some other device, these chopped pices are put in the silo and thoroughly packed by tramping. When the silo is filled, a cover of leaves, stallis or some other substance, is placed over the top to exclude the air.

Then begins a process that has been called by many names - fermenting, cooking, predigesting, ete. But whatever this process is ealled, it contimues for a few days, and then the green feed has become silage. A little leak of air, the exposing of the silage to air, or any other way of letting air to it will turn it dark. or develop certain trpes of mold. These molds are invariably unlealthy, and in many cases are absolutely poisonous, and have heen known to kill horses, and sometimes cattle and other stock. In this connection it is easy to see why the inside walls of the silo should be smooth and the diameter the same, for the green feed "settes" from one-fomrth to one-tlinel and if the inner" walls were uneven it would leave air chinks as the silage settled.

\section{Good and Bad Silage}

Oceasionally a man is found who eondemns silage and the silo-les says from bad experience. It were almost as well to say farming is hat beeausis there happens to be some lad farmers. Good silage is good for almost any kind of stock, but poor silage is liable to do injury to stock, espeeially to horses.

For the purpose of making gains in feeding eat- the-the thing that this booklet was written aboutthere hats been no feed that has shown stach ecomony as grood silagre; but it is mohesitatingly moldy or otherwise defective silate is 10 be avoided. There is no difficulty about making good silage crops can be harvested and cared for more cheaply as silage than in almost any other way, particularly when it is remembered that in this form there is more feeding value to be had than in saving the erop in any other way. In a general way, it may be sild that putting up a silo is the equivalent of having a third more land in cultivation, but, as this equivalent of one-third more land is in the form of a silo, it takes neither teams nor plows to cultivate it.

\section{Quantity of Silage Fed and Results}

In a teeding term of four months, two and one. half tous of silage has seemed to be about the most economic amount, per steer. 'The lowest average production of Kafir (Corn or similar crop), per acre, that has been given by any responsible observer is 8 tons, which means that one acre will tatten flree steers. 'Taking the average gain of steers in T'exas, this would mean that one acre would produce 1,000 pounds of beet-this at $71 / 2$ eents per pound would be $\$ 63.70$, after having deducted the average cost of all other feeds used in the T'exas tests. There are well-authenticated cases of ehoice irrigated acres producing 30 tons of silage per acre.

\section{Worn-out Cotton Lands}

With distressing frequency, cotton farmers are beginning to inquire "what can we do to restore our worn-out cotton lands." Not only is this true of a few farmers licre and there, but the inquiries sometimes come from whole communities, and oceasionally from counties and sections of States-in other words, the inquiry is broad and deeply significant. Lands that were rich and well located, and that in former years produced from a bale to a bale and a half per acre have been reduced to a halt-bale or even less per acre.

Such communities and farmes are reminded that the 267 tests herein examined show that the fertiliring value of feeds given to a norther'u steer would s:ll in the open marliet for $\$ 17.93$, and that of this value, $\$ 7.55$ eame from the cotton-secd products of southerm aeres. In other words, for every steer fattened in the north there was $\$ \overline{7.55}$ in fertilizer. values taken from soutlern farms and placed on northern fields. 'I'he cotton farmer has not simply been selling cotton-seed, he has heen selling his tamm. If lie doubts this, it is only needful to remind him of his inquiry about what he can do to restore his worn-out cotton lands; lands that perhaps at one time produced a bale or more per acre. but that now gives but a half hale or less-if the production is reduced hy half, there can be no question but that he has sold halt lis farm.

At the sime time, the northern farmer who has bought the cotton-seed products has cmriehed his land, and is not only making a profit oft the feeding, but is adding value constantly to his land. Tot the southern farmer marvels at the hich prices of lands in the north and sighs over the lower values in the solith.

But this is not all. Cotton-seed produets by 1ha. 
shipload go to Europe. Cotton-seed meal is used very extensively in feeding European cattle. Witlı this chain on the fertility of southern soils by the sale of cotton-seed, there is little cause to marvel at there being a cry about worm-out cotton lands.

In this comnection, it is well to remember that the lint takes very little fertility from the soil, but that the seed draw very heavily upon the land's ricimess; it is in reference to cotton-seed and its products that the ahove statements are directed.

If it pays the northeru farmer to ship cottonseed prochucts to his eattle-feeding peus, it will pay the southern farmer to use them when he does not have to ship them. If it pays the European fiamer to carry them across the Atlantic to his feed yards, it will pay the southern farmer to use them at home.

Only 5.7 per cent of the entire area of the south is in cotton, yet that small portion of its area supplies 59 per cent of the world's cotton; this is the statement of a bulletin of the State of 'T'ennessee published in April, 1914. If the entire supply of the world were to come from the south, only about 10 per eent of its lands would be under cultiration. There are millions upon millions of acres of idle agricultural land that could be used to enltivatc feed crops, or used as pasture. Cattle can be growi. on these pastures, and fattened upon the feed cropss. The cotton-seed proclucts ean be fed at home and the fertility of the lands be kept up, instead of being used to inerease the value of northern and Furopean acres.

It would be well if a maxim from dozens of the bulletins of the United States Department of Agriculture-a maxim that occurs in almost every good book on farming - a maxim that is reflected in the amount of money that manufacturers are putting into making manure spreaders, and that northern farmers are buying and finding profitalle-a maxim that has been almost like a proverb among European farmers for centuries-it would he well it southwestern and western farmer's would adopt it into their every day farm methods-this in the maxim: "No man can maintain the fertility of his farm without the constant feeding of live-stock upon it."

\section{Fertilizing Value of Feeds}

It may help to realize the value of the fertilizing elements in feeds, in the forms of mamures, by calling attention to the commercial value of these tertilizing elements in the feeds consumed by the cattle in the 267 tests herein treated. The figures are as follows :

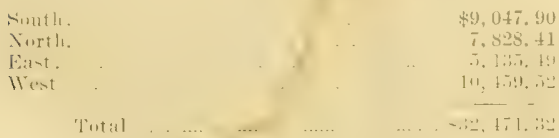

This is considerably more than lalf the cost of the feeds used. The values above given are based on the Fertilizing T'alues in Feeds as shown in the tables in TI. A. Irenry's book on Feerls and Feeding on pages 582 to 589 . It is well, lowever, to luint wn llat as the amount of feeds used in the sonth wais much less, per steer, than were used in 1lu now 1 , it would not be expected that the fertiliz-

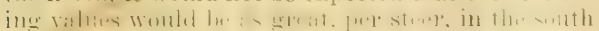
as they were in the north. The value assigned to the fertilizing elements in feeds are their fair avercommercial value, as follows: Nitrogen, 18 cents pound; potash and phosphate, each 5 cents per lound.

\begin{tabular}{|c|c|c|c|c|c|c|c|c|}
\hline & \multicolumn{2}{|c|}{ SOUTH I } & \multicolumn{2}{|c|}{ NоRTH } & \multicolumn{2}{|c|}{ EAST } & \multicolumn{2}{|c|}{ WEST } \\
\hline & $\begin{array}{l}\text { Per } \\
\text { Head }\end{array}$ & $\begin{array}{l}\text { Per } 100 \\
\text { Younds } \\
\text { Gain }\end{array}$ & $\begin{array}{l}\text { Per } \\
\text { Head }\end{array}$ & $\begin{array}{c}\text { Per } 100 \\
\text { Youads } \\
\text { Gain }\end{array} \mid$ & $\begin{array}{l}\text { Per } \\
\text { Head }\end{array}$ & $\left|\begin{array}{c}\text { Per 11,0 } \\
\text { Pounds } \\
\text { Gain }\end{array}\right|$ & $\begin{array}{l}\text { Per } \\
\text { Head }\end{array}$ & $\begin{array}{l}\text { Per } 100 \\
\text { Pounds } \\
\text { Gain }\end{array}$ \\
\hline Cost of Gains............. & $\$ 12.33$ & $355.31 \mid 8$ & 830.711 & $\mid \$ 9.0818$ & $\$ 18.25$ & $|\$ 10.86| \$$ & $\$ 20.241$ & | $\$ 819$ \\
\hline erlilizer Value. & 3.65 & 3.701 & 17.93 & 5.321 & 13.27 & I $7.8+1$ & 11.081 & $1 \quad 4.47$ \\
\hline Cost, Less Ferulizer Value . & 3.62 & 1.58 & 12.78 & 3.76 & 4.98 & 3.02 & 9.16 & 3.75 \\
\hline
\end{tabular}

The for tilizing values given above represent what it is possible to return to the land by feeding eattle, and with proper care of the manures. 'fhey mean just that much to the erop of succeeding years. They mean the difference between keeping up thc land to its highest state of fertility and production, and seeing the lands degenerate till their owners be. gin to incuire, "What can we do to restore our wornout land!" They mean the difference between lands that are hard to enlivate, and lands that are mellow and easy to till. They mean the difference bestween lands that allow moisture to evaporate with much readiness, and lauds that hold moisture very tenaciously. They mean (in sections where alkaline water has to be used for irrigation), the difference between hard, crusty soils and a stunted crop, and mellow soils with better crops.

It will not require but a few years to demonstrate to any practical farmer that, from the standpoint of moisture alone, an abundanee of mamme on land is worth more than artesian wells, though it is framkly said irrigation is most desirable if the ex. peuse attendant up it it not too excessive for the crops raised.

But the great fact for the farmer-feeder is that when the manure is returned to his land, little or nothing of value has been taken from his farm; whereas, if he sells his erops, he is rapidly disposing of his farm, and in a few years he will have little left but "wornout land".

'The figures given above showing the cost of feeding cattle, after fertilizing values are returned to the land, are not entirely legitimate; they rather show how much of the fertility of his lands he has sold in selling eattle, as compared to what he would sell in putting his erops on the market. It is, however, very different when the southern farmer sends his land's fertility to the north and to Europe to inerease the value of those acres and deplete the lands of the south. A motto ought to be: "Feed southern feeds to southern live-stock," and a companion one, "Don't send the fertility of southern acres to enrich worthern and European fields."

\section{Conclusion}

This entire booklet is one set of facts and conclusions. It is practically incapable of being summarized. But the one broad, new fact that has been brought to the attention of the public is the direct, positive and almays present influence of climate on the cost of making gains in fattening cattle, or, in fact, in raising cattle. This big, new fact inevitably points to the south, and particularly to the western or drier portion of the south as the great beet-producing section of the United States. 


\section{Explanation of Cuts 1 to 7}

In ents 1 to 7 are presented the detailed figures and tables on which the statements and comelusions alrealy expressenl are based. Thlese taliles coser ten veats of foeling tests in thirteen states-a few anterlating these ton years. Every availalile puldishet fenting tesi ha. leen used, where the reports were suffieimely full to be tahulated. Sometimes there were eertain itents in the published revorts that were omitted that had to he eal. eulated from other items that were aiven, e. G., the total pounds of teed, per steer, from the pounds fent pror diay. Sometimes the current ("ost of fechls were not given; agrain, the cost of making gains were shom if feeds hat been at certain varied prices.

In euts 1 to 7 the same numlice of proumls of feed are given as was published in the state reports, lut in all cases the local priees wre thistegaried, and the micus used that are given in the 'Tahle of General I)ita. Calen. lations have not been carried into clecimals, and in the very extenterl exaleulations some minor errors may thave oceirred, hut they are so trivial that they will not affeet in any way the general results il realy stated.

There are four groups of tests. The southern groul includes Alabama, Mississipji and rexis; the northeri group includes Illinois, Inliana and Miehisan; the east. ern group inclules Nortl Carolina. Temnessee and Vir. ginia; the western group imeluhes Kansis, Missouri, Ne. Braska, South Dakota and Washington. The tests in each groul are, for envenienee, mumbered conisentively nzuler the beading, "Group No.",

On the left end of the talle for each yroup are columns showing (1) test number which corresponuls to the one given under the hend "Group No.," (2) the length in days, of the test; (3) the late of the test; $(t)$ the unmbet of the State bulletin from which the test was taken.

To the right of these columns, rmuing along the top of these tables, are four rows of figures. In the upper. most row is found both the "Gromu No." of the test and the number of eattle used in each particular test: the next three roms of figures contain (1) the average initial weight of the eattle. (2) the average gain per heal, and (3) the average gain per day. Below the heary line is found the numlier of poumds of the different kinds of feeds used per steer in the different tests. Beneath the heary liue rumning umber the statement of the pound of feeds used, is the cost of these feeds per steer aceording to the prices in the Tahle of (ineral Data. Below the heavy line running mole the cost of feerls, is the cost, per lieat, and per 100 pounds of gain, for each test.

The extreme right colum gives the averages for each group of tests. Averages heretofore given cover all groups in cuts 1 to 7 .

\section{USES OF FIGURES AND TABLES IN CUTS 1 TO 7.}

The value of the $4 \bar{t}$ different kinds of fecils used in these tests can be studied in detail in these tables by the practical feeder-studied with reference to season, loeation, cost and from any other angle. This study will re lieve the necessity for unnecessary and sometimes cxpensive experinents in feeding, for the very facts sought in these experiments are contained in these tables. Among the thingrs that will beenme realily apparent in the study of these tables is that silage, particularly in large quantities, almost invariably reluces the cost of grains; that hay, cotton-seed hulls and other dry ronishames ald to the expense of gains; that whole grain is more expensive than meals, that where meals are nsel there are no hogs fattcned with cattle. But the facts that may he wained br the study of these fables are so mumerous and valuable that no feeiler or farmer ean afford to ennsider them as "mere dry figures and tables."

These tables furnish, for the first time, in a form that makes a comparison jossible, the accumulaterl knowledge of feeling tests from the whole enutry. They are aver. ares, and to not represent the lowest onst of making gains, but from them the uractical feeler and farmer ean get the knowledge that will enable him to make the cheapest gains.

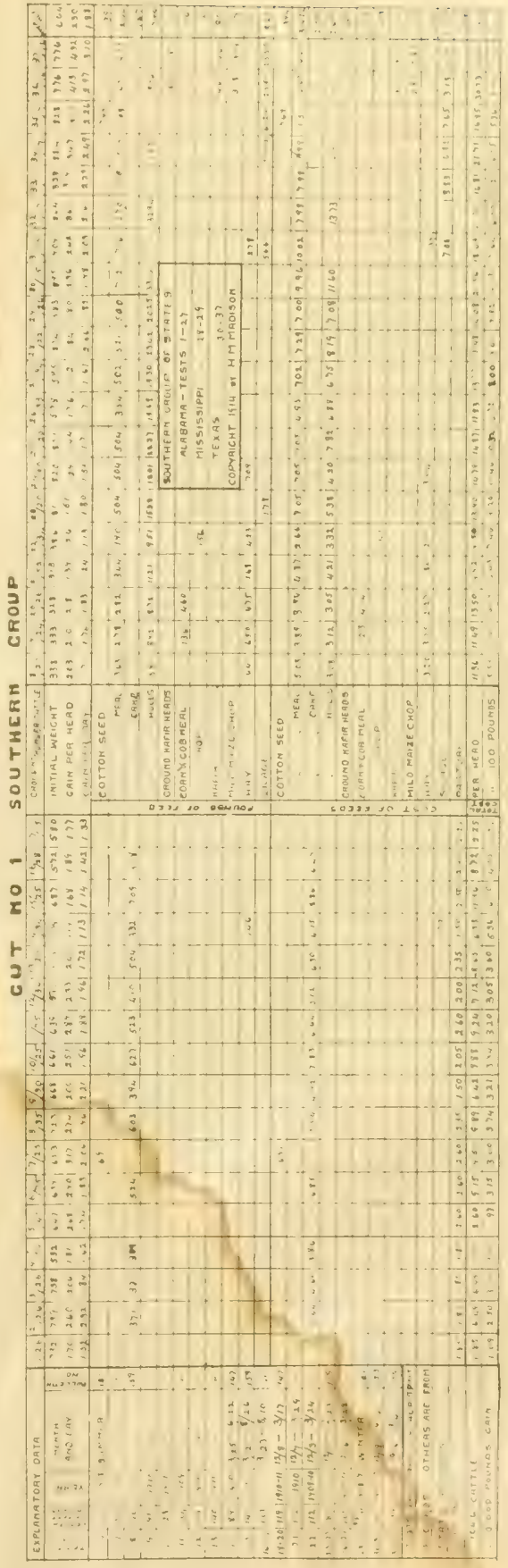



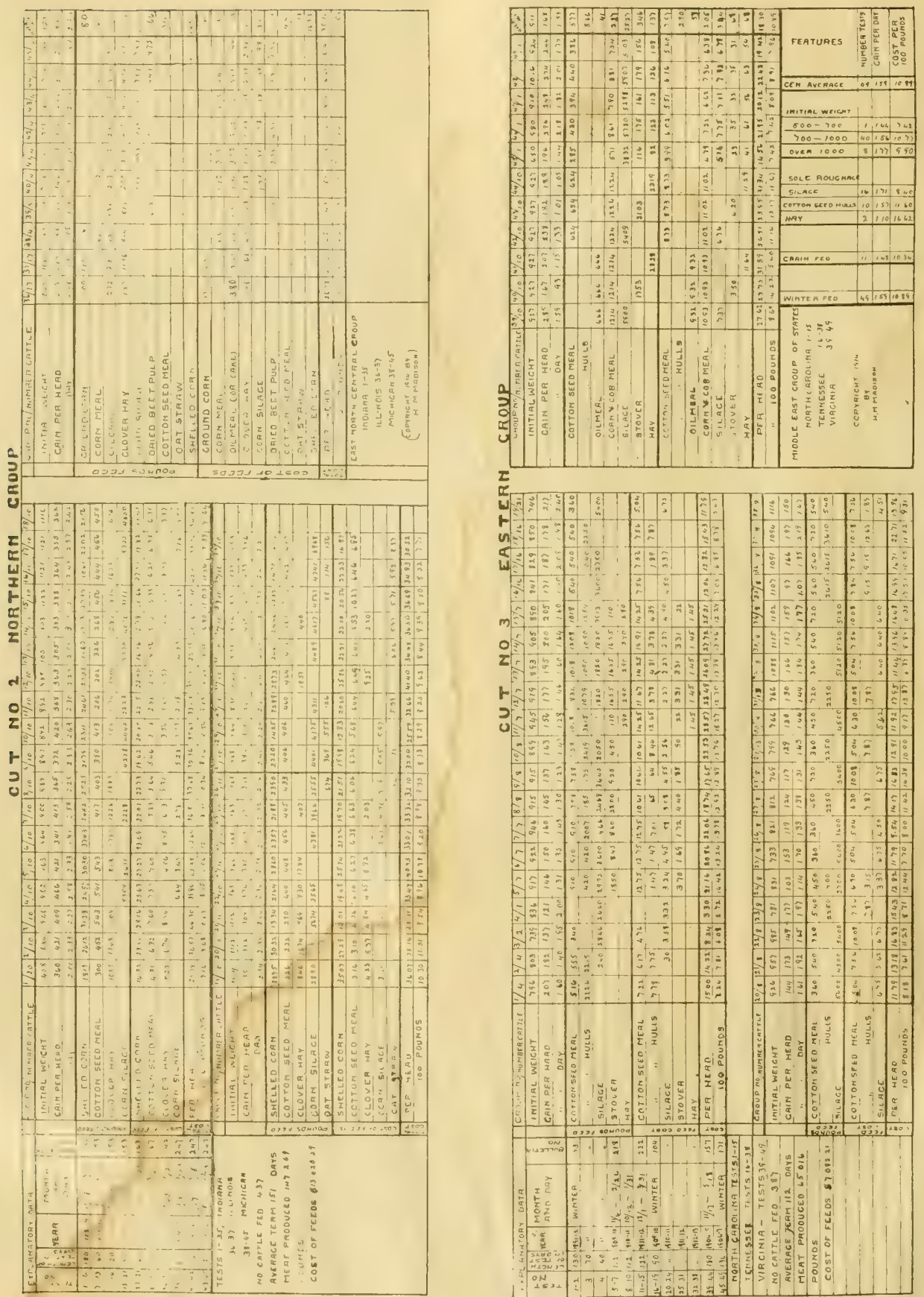
FARMING AND FEEDING
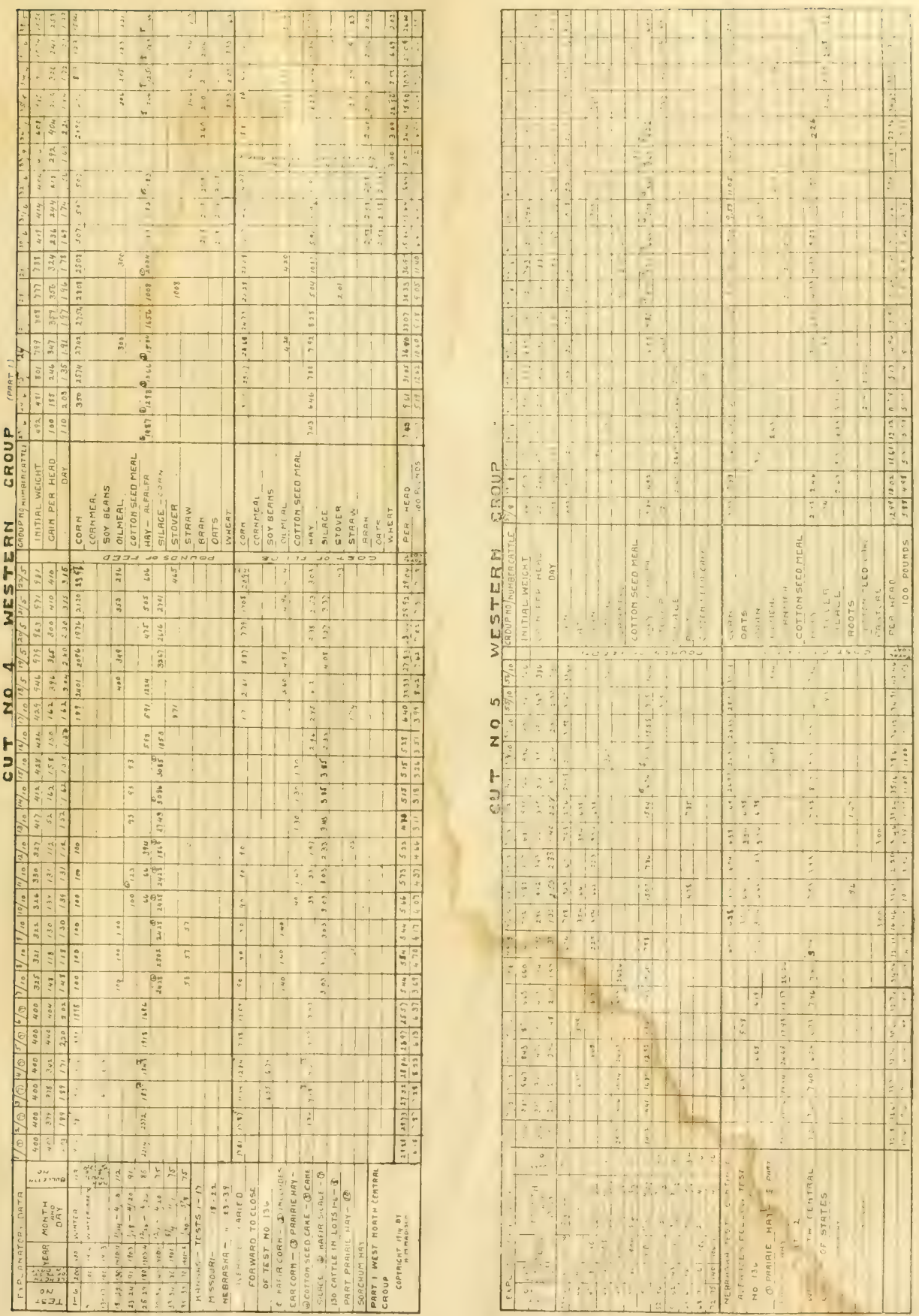
FARMING AND FEEDING
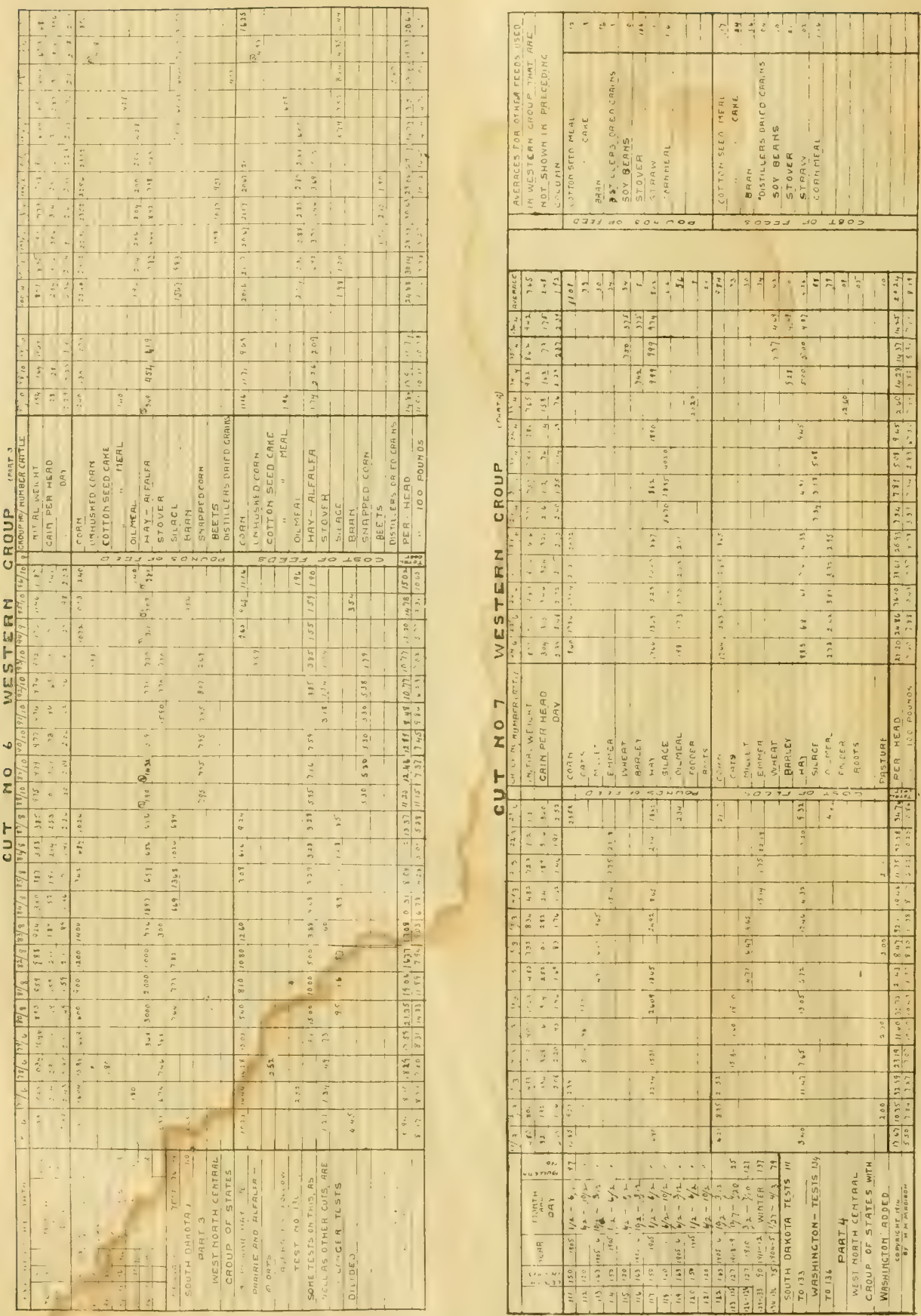


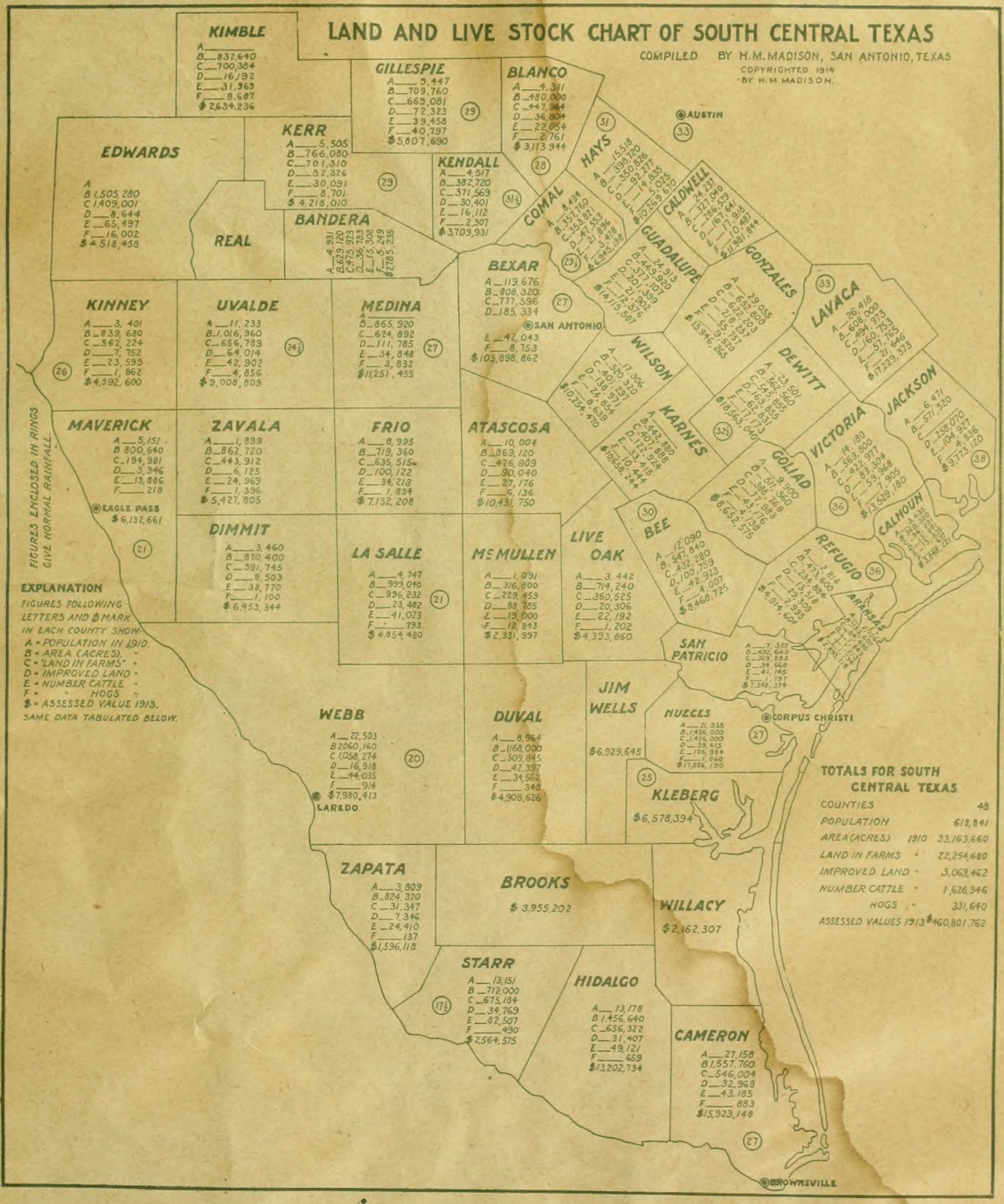



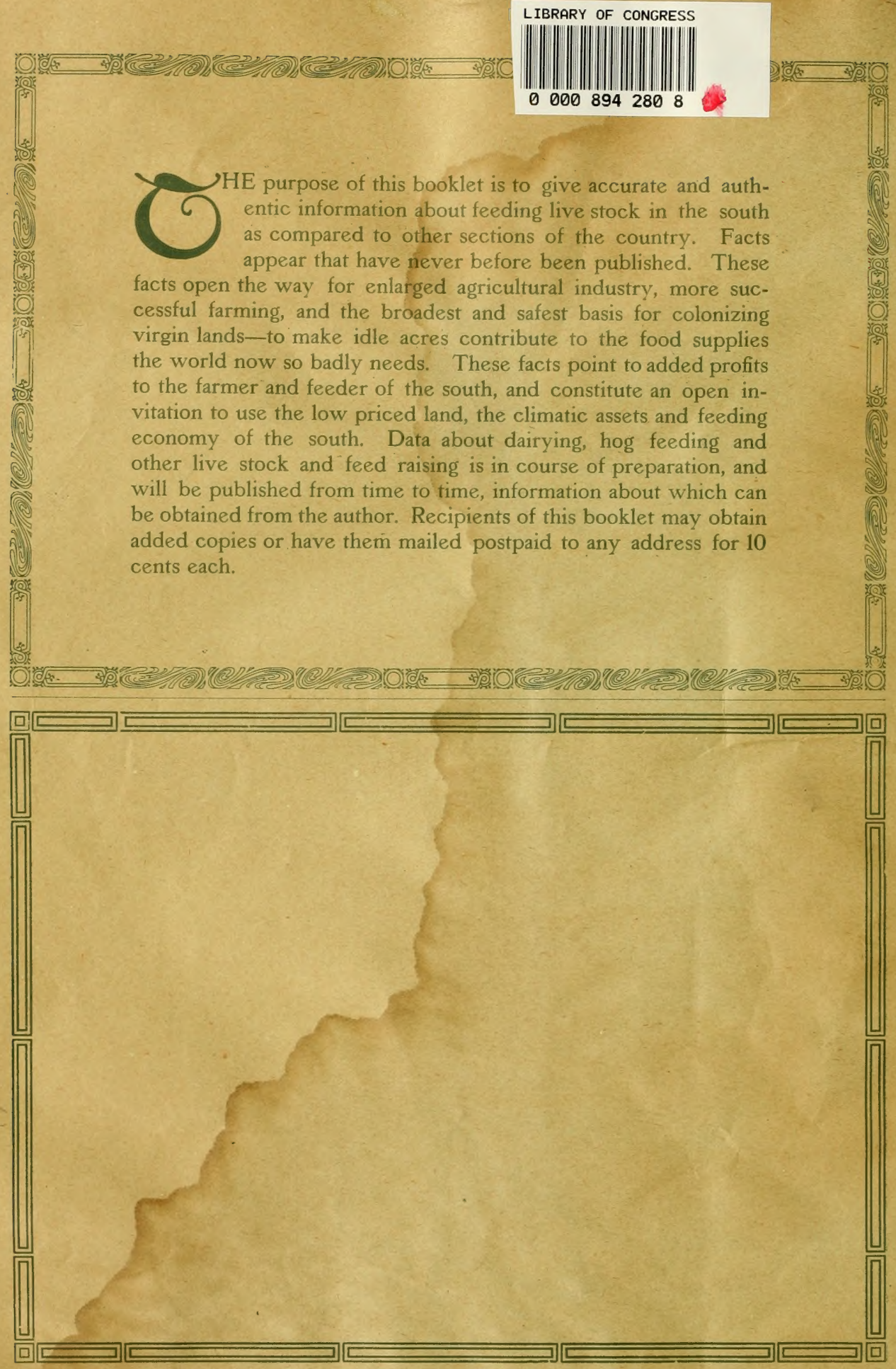
LIBRARY OF CONGRESS

00008942808 